\title{
Herlina Pusparani : Media Quizizz Sebagai Aplikasi Evaluasi Pembelajaran Kelas VI di SDN Guntur Kota Cirebon
}

\section{MEDIA QUIZIZZ SEBAGAI APLIKASI EVALUASI PEMBELAJARAN KELAS VI DI SDN GUNTUR KOTA CIREBON}

\author{
Herlina Pusparani, M. Pd. \\ SDN Guntur Kota Cirebon, \\ Alamat e-mail: pusparani.ak@gmail.com
}

\begin{abstract}
This study aims to describe quizizz as a learning evaluation application and improve learning evaluation results as a fun learning. This classroom action research was conducted in two cycles with two learning meetings in each cycle. Each cycle consists of planning, implementing, observing, and reflecting. Every meeting, students work on evaluations through quizziz. The subjects were 32 students of class VI A SDN Guntur, Cirebon City. The results of this study indicate that quizizz is one of the learning media for learning evaluation activities. There is an interaction when students work on learning evaluations, they feel motivated to do the evaluation. Students can improve their learning outcomes as indicated by the increase in quizizz results. In the first cycle of the first meeting, the number of students who completed was $37.5 \%$. This result increased in the second meeting to $62.5 \%$. In the second cycle of the first meeting reached $87.5 \%$, and in the second meeting reached $100 \%$. All students can achieve completeness in the evaluation of learning because students are motivated to be able to do quizzes, so that students' understanding of the material increases. This causes the learning outcomes of students increase.
\end{abstract}

Keywords: learning evaluation, media, quizizz

\begin{abstract}
ABSTRAK
Penelitian ini bertujuan untuk mendeskripsikan media quizizz sebagai aplikasi evaluasi pembelajaran kelas dan meningkatkan hasil evaluasi pembelajaran melalui quizizz sebagai aplikasi pembelajaran yang menyenangkan. Penelitian tindakan kelas ini dilakukan dalam dua siklus dengan dua pertemuan pembelajaran di setiap siklusnya. Setiap siklus terdiri dari perencanaan, pelaksanaan, observasi, dan refleksi. Setiap pertemuan, peserta didik mengerjakan evaluasi pembelajaran melalui quizizz. Subyek penelitian ini adalah peserta didik kelas VI A SDN Guntur Kota Cirebon sebanyak 32 peserta didik. Hasil penelitian menunjukkan bahwa quizizz merupakan media pembelajaran untuk kegiatan evaluasi pembelajaran. Terdapat interaksi ketika peserta didik mengerjakan evaluasi pembelajaran, sehingga peserta didik merasa termotivasi untuk mengerjakan evaluasi dan merasa senang. Peningkatan hasil belajar ditunjukkan dari peningkatan hasil quizizz. Pada siklus pertama pertemuan pertama, jumlah peserta didik yang tuntas sebanyak $37,5 \%$. Hasil ini meningkat pada siklus pertama pertemuan kedua menjadi $62,5 \%$. Pada siklus kedua pertemuan pertama, ketuntasan mencapai $87,5 \%$, dan pada siklus kedua pertemuan kedua, ketuntasan mencapai $100 \%$. Seluruh peserta didik dapat mencapai ketuntasan dalam evaluasi pembelajaran dikarenakan peserta didik semakin termotivasi untuk bisa mengerjakan quizizz, sehingga pemahaman materi peserta didik meningkat. Sehingga hasil belajar peserta didik meningkat.
\end{abstract}

Kata kunci: evaluasi pembelajaran, media, quizizz 


\section{PENDAHULUAN}

Pembelajaran tematik terpadu merupakan pendekatan pembelajaran yang memadukan berbagai kompetensi dari berbagai mata pelajaran ke dalam berbagai tema. Pada proses pembelajaran tematik terpadu disusun saling terkait antara mata pelajaran satu dengan mata pelajaran lainnya, sehingga memberikan pengalaman bermakna kepada peserta didik. Untuk mencapai pendidikan yang bermutu dibutuhkan upaya secara terus menerus untuk selalu meningkatkan kualitas pembelajaran. Kualitas pembelajaran dapat diartikan sebagai intensitas keterkaitan sistematik dan sinergis guru, peserta didik, kurikulum dan bahan belajar, media, fasilitas, dan sistem pembelajaran dalam menghasilkan proses dan hasil belajar yang optimal sesuai dengan tuntutan kurikuler. Suatu kualitas pembelajaran dikatakan rendah apabila keefektivitasannya belum dapat tercapai secara maksimal.

Salah satu faktor tercapainya pembelajaran yang efektif, efisien, dan menyenangkan adalah dengan menggunakan media pembelajaran. Abidin (2014:174) menjelaskan media pembelajaran adalah alat bantu proses belajar mengajar. Segala sesuatu yang dipergunakan untuk perhatian dan kemampuan pebelajar sehingga dapat mendorong terjadinya proses belajar.

Sedangkan menurut Shoimin (2013:41) media sebagai komponen strategi pembelajaran merupakan wadah dari pesan yang oleh sumber atau penyalurnya ingin diteruskan kepada sasaran atau penerima pesan. Media mencakup semua sumber yang diperlukan untuk melakukan komunikasi dengan peserta didik.

Berdasarkan pendapat beberapa ahli tersebut, maka dapat dikatakan bahwa media pembelajaran adalah segala sesuatu yang digunakan untuk menyampaikan pesan kepada peserta didik sehingga muncul minat belajar siswa dan mengakibatkan suasana pembelajaran yang kondusif.

Media pembelajaran, dapat meningkatkan kualitas pembelajaran karena fungsinya membuat pembelajaran lebih kontekstual, nyata, dan menarik. Suyanto dan Djihad (2012:246-247) menyebutkan fungsi media pembelajaran secara umum diantaranya adalah:

a. Menyaksikan benda yang ada atau peristiwa yang terjadi pada masa lampau. Dengan perantaraan gambar, potret, slide, film, video, atau media yang lain, siswa dapat memperoleh gambaran yang nyata tentang benda 
atau peristiwa sejarah.

b. Mengamati benda atau peristiwa yang sukar dikunjungi, baik karena jaraknya jauh, berbahaya, atau terlarang.

c. Memperoleh gambaran yang jelas tentang benda atau hal-hal yang sukar diamati secara langsung karena ukurannya terlalu besar atau terlalu kecil.

d. Mendengar suara yang sukar ditangkap dengan telinga secara langsung.

e. Mengamati dengan teliti binatang-binatang yang sukar diamati secara langsung karena sukar ditangkap.

f. Mengamati peristiwa-peristiwa yang jarang terjadi atau berbahaya untuk didekati.

g. Mengamati dengan jelas benda-benda yang mudah rusak atau sukar diawetkan.

h. Dengan mudah membandingkan sesuatu. Dengan bantuan gambar, model, atau foto, siswa dapat dengan mudah membandingkan dua benda yang berbeda, seperti sifat, ukuran, warna, dan sebagainya.

i. Dapat melihat secara lambat gerakan-gerakan yang berlangsung secara cepat.

j. Dapat melihat secara cepat suatu proses yang berlangsung secara lambat.

Media pembelajaran tidak hanya digunakan untuk menyampaikan materi pembelajaran, namun dapat pula digunakan ketika kegiatan evaluasi pembelajaran. Media yang sering digunakan untuk kegiatan evaluasi pembelajaran adalah kuis interaktif yang dikerjakan secara dalam jaringan.

Keberhasilan pembelajaran dan penggunaan media pembelajaran dapat dilihat dari tingkat pemahaman penguasaan materi serta hasil belajar peserta didik. Semakin tinggi tingkat pemahaman peserta didik terhadap materi serta hasil belajarnya, maka semakin tinggi pula tingkat keberhasilan pembelajaran. Namun dalam kenyataannya hasil belajar yang dicapai peserta didik masih rendah. Pembelajaran selama ini belum berhasil dan menyebabkan hasil belajar peserta didik yang masih rendah.

Permasalahan tersebut didukung dengan data permasalahan ketuntasan belajar klasikal peserta didik kelas VI A SDN Guntur Kota Cirebon dalam pembelajaran Tema 3. Temuan yang ada sebanyak 28 peserta didik dari 32 peserta didik memiliki skor di bawah Kriteria Ketuntasan Minimal (KKM) yaitu 70 
$(2,66)$ dengan presentase $72 \%$, sedangkan presentase peserta didik yang memiliki skor di atas KKM yaitu $28 \%$. Ketika pembelajaran peserta didik cenderung pasif dan kurang antusias. Peserta didik mengalami kesulitan dalam memahami materi. Selain itu, terdapat beberapa perilaku menyimpang peserta didik seperti tidak memperhatikan, bermain dengan teman sebangkunya dan mengantuk. Kondisi tersebut memerlukan media pembelajaran yang menarik dan inovatif khususnya media untuk kegiatan evaluasi pembelajaran. Guru harus melakukan pendekatan yang sesuai untuk mengembalikan perhatian peserta didik pada pembelajaran.

Guru melakukan inovasi penggunaan media pembelajaran berupa penggunaan media pembelajaran untuk kegiatan evaluasi pembelajaran. Salah satu media yang digunakan ketika kegiatan evaluasi pembelajaran secara daring adalah quizizz. Quizizz merupakan sebuah aplikasi kuis interaktif yang berasal dari Santa Monica, California, Amerika Serikat. Quiziiz adalah aplikasi yang menyediakan bentuk soal formatif dengan berbagai macam pilihan yang disajikan dengan menyenangkan dan menarik bagi semua peserta didik.

Quizizz merupakan salah satu inovasi media dalam kegiatan evaluasi pembelajaran. banyak fitur yang bisa digunakan seperti soal pilihan ganda, soal isian, maupun soal uraian. Aplikasi ini dapat digunakan di manapun peserta didik berada. Citra dan Rosy (2020:263) menjelaskan bahwa quizizz adalah aplikasi pendidikan berbasis game yang membawa aktivitas multi pemain ke ruang kelas dan menjadikan pembelajaran dalam kelas lebih menyenangkan dan lebih interaktif. Wibawa, Astuti, dan Pangestu (2019:250) menyebutkan bahwa aplikasi quizizz mempunyai fitur yang secara umum dapat memfasilitasi guru maupun peserta didik dalam proses pembelajaran. Hal tersebut menunjukkan bahwa aplikasi quizizz bisa digunakan untuk inovasi pembelajaran.

Penelitian terdahulu tentang penggunaan quizizz dalam evaluasi pembelajaran dilakukan oleh Sugian Noor (2020) yang berjudul, "Penggunaan Quizizz Dalam Penilaian Pembelajaran Pada Materi Ruang Lingkup Biologi Untuk Meningkatkan Hasil Belajar Siswa Kelas X.6 SMA 7 Banjarmasin". Penelitian tersebut merupakan penelitian lapangan yang bersifat deskripsi kualitatif. Hasil penelitian menunjukkan bahwa terjadi peningkatan hasil belajar sebesar $20 \%$. Peningkatan tersebut terjadi karena quizizz menjadikan penilaian menarik dan 
menyenangkan sehingga memotivasi peserta didik untuk berhasil.

Selanjutnya, penelitian dari Sri Mulyati dan Haniv Evendi (2020) yang berjudul, "Pembelajaran Matematika Melalui Media Game Quizizz Untuk Meningkatkan Hasil Belajar Matematika SMP 2 Bojonegara". Jenis penelitian tersebut adalah penelitian tindakan kelas yang menggunakan teknik pengumpulan data tes dan observasi. Hasil penelitiannya menunjukkan bahwa terjadi peningkatan hasil belajar peserta didik sebesar $63 \%$ pada siklus 1 dan sebesar $78 \%$ pada siklus 2 . Hal tersebut menunjukkan bahwa quizizz efektif dalam meningkatkan hasil belajar peserta didik.

Berdasarkan uraian penelitian terdahulu, dapat disimpulkan bahwa quizizz adalah salah satu apikasi yang bisa digunakan dalam penilaian pembelajaran. Fitur quizizz yang bervariasi membuat peserta didik merasa senang dan nyaman ketika mengerjakan penilaian. Sehingga peserta didik termotivasi untuk bisa menyelesaikan penilaian dengan hasil yang maksimal.

Berdasarkan uraian latar belakang tersebut, dilakukan penelitian kelas yang bertujuan untuk mendeskripsikan kegiatan evaluasi dalam pembelajaran melalui quizizz sebagai aplikasi evaluasi pembelajaran di kelas VI A SDN Guntur Kota Cirebon dan untuk meningkatkan hasil belajar peserta didik pada pembelajaran tema 3 di kelas VI A SDN Guntur Kota Cirebon.

\section{METODE PENELITIAN}

Penelitian ini merupakan penelitian tindakan kelas yang terdiri dari dua siklus penelitian. Setiap siklusnya terdiri dari perencanaan, pelaksanaan, observasi, dan refleksi penelitian. Setiap siklus terdiri dari dua pertemuan. Penelitian ini dilaksanakan pada bulan September sampai dengan bulan Oktober 2020 di SDN Guntur Kota Cirebon. Subyek penelitian ini adalah peserta didik kelas VI A yang berjumlah 32 peserta didik. Penelitian ini diawali dengan perencanaan berupa skenario pembelajaran di setiap pertemuan, kemudian pelaksanaan penelitian sesuai dengan perencanaan. Setelah mendapatkan hasil, hasil tersebut diobservasi dan dilakukan refleksi. Hasil refleksi digunakan untuk perencanaan pertemuan selanjutnya. Penelitian ini menggunakan instrumen berupa soal yang dikemas dalam aplikasi quizizz. Pelaksanaan prosedur penelitian yang dilakukan peneliti adalah sebagai berikut. 
Teknik pengumpulan data yang digunakan dalam penelitian ini adalah teknik tes menggunakan aplikasi quizizz. Teknik analisis data pada penelitian ini menggunakan teknik analisis data kuantitatif untuk mengukur keberhasilan peserta didik dalam dua siklus penelitian.

\section{HASIL DAN PEMBAHASAN}

Hasil dari penelitian ini, didapatkan bahwa media quizizz yang dapat diunduh di playstore atau dijelajahi melalui laman web quizizz.com memiliki berbagai fitur sebagai berikut.

1. Student-Paced, dimana pertanyaan dalam kuis akan muncul di layar masing-masing peserta didik, sehingga mereka dapat menjawab pertanyaan dengan langkah mereka sendiri dan dapat meninjau jawaban mereka.

2. Quizizz dapat dimainkan di browser manapun, di smartphone, PC, Laptop, tablet, dan perangkat lainnya yang bias menjalankan iOS/Mac, Android, Windows atau system operasi Linux. Quizizz juga dihadirkan dalam bentuk aplikasi pada iOS dan Android, selain bias diakses menggunakan browser.

3. Terdapat ribuan kuis yang dipublikasikan, dimana para guru bias menggunakan kuis-kuis tersebut untuk dilatihkan kepada peserta didiknya. Selain itu, peserta didik juga bias mencari kuis sendiri.

4. Quiz Editor, quizizz memiliki editor kuis yang baik. Pengguna dimudahkan untuk mengunggah gambar atau media lain pada soal yang dibuat, bisa mengambil soal dari kuis yang dibuat, dan menyimpan soal secara otomatis.

5. Quiz Report, quizizz memiliki fitur untuk menampilkan laporan hasil mengerjakan kuis. Laporan ini bisa dicetak dan diteruskan secara langsung melalui email kepada orang tua peserta didik. Laporan kuis ini disajikan secara terperinci dan menampilkan analisis butir soal.

6. Quiz Costumization, Guru memiliki beberapa opsi untuk menyesuaikan sesi kuis mereka untuk beralih tingkat kompetisi, kecepatan, dan faktor lainnya.

Mulyati, S. dan Evendi, H. (2020:66) menyebutkan bahwa quizizz memiliki berbagai macam karakteristik yang digunakan dalam permainan sepert meme, avatar, tema, dan musik permainan. Quizizz juga memiliki fitur papan peringkat 
(leaderboard) yang digunakan untuk menunjukkan peringkat selama permainan. Fitur-fitur ini membuat peserta didik tertarik dan termotivasi dalam menyelesaikan soal dengan benar.

Berdasarkan uraian tersebut, dapat disimpulkan bahwa aplikasi quizizz memiliki fitur yang lengkap dan fleksibel. Hal ini dapat memudahkan peserta didik untuk mengerjakan soal di manapun dan kapanpun. Guru juga diberikan kemudahan untuk membuat kuis dan mengatur penggunaan kuis. Bahkan, guru dapat langsung mendapatkan hasil analisis soal yang bias diteruskan atau dikirimkan langsung kepada orang tua peserta didik. Quizizz merupakan salah satu media evaluasi pembelajaran yang efektif dan efisien digunakan.

Pada quizizz, terdapat 5 jenis pertanyaan interaktif, yaitu pilihan ganda, daftar cek, isian, polling, dan uraian. Media ini memiliki tampilan desain yang menarik dan interaktif. Hal ini membuat peserta didik merasa senang ketika mengerjakan evaluasi pembelajaran. Hal ini sesuai dengan pendapat Citra dan Rosy (2020:263) yang menjelaskan bahwa quizizz memiliki kelebihan yaitu soal-soal yang disajikan memiliki batasan waktu, dalam hal ini peserta didik diajarkan untuk berpikir secara tepat dan cepat dalam mengerjakan soal yang ada. Kelebihan lain yang ada pada quizizz adalah jawaban dari soal yang ada akan ditampilkan dengan warna dan gambar serta terlihat pada komputer guru (sebagai operator) dan dalam perangkat peserta didik akan berganti secara otomatis sesuai dengan urutan soal yang disajikan.

Sebelum melaksanakan penelitian, peneliti menyiapkan perangkat pembelajaran termasuk soal yang sudah dibuat menggunakan quizizz. Guru bisa mengatur permainan secara langsung, penugasan, individu, tim, maupun tes (hanya bisa dikerjakan satu kali).

Pada siklus pertama pertemuan satu, peneliti mengenalkan quizizz kepada peserta didik dan melaksanakan kegiatan evaluasi pembelajaran menggunakan quizizz. Hasil evaluasi pembelajaran tersebut, terdapat 12 peserta didik yang nilainya mencapai kriteria ketuntasan minimal (KKM). Sedangkan 20 peserta didik lainnya masih di bawah KKM. Hal ini dikarenakan peserta didik belum memahami betul materi pembelajaran.

Hasil penelitian siklus pertama pertemuan dua, peserta didik yang nilainya di atas KKM meningkat menjadi 20 peserta didik. Masih ada 12 peserta didik yang 
belum tuntas. Pada pertemuan kedua, peserta didik mulai antusias memahami materi pembelajaran untuk melaksanakan kegiatan evaluasi pembelajaran.

Hasil penelitian siklus kedua pertemuan satu, sebanyak 28 peserta didik memiliki nilai di atas KKM. Sebanyak $87,5 \%$ peserta didik sudah tuntas. Hasil ini menunjukkan bahwa sebagian besar peserta didik sudah memahami materi pembelajaran. Meskipun masih ada beberapa peserta didik yang kesulitan memahami materi, namun motivasi peserta didik melaksanakan evaluasi pembelajaran menggunakan media quizizz semakin meningkat. Peserta didik merasa senang mengerjakan soal interaktif secara langsung, penugasan, maupun secara kelompok atau tim.

Hasil penelitian siklus kedua pertemuan dua, sebanyak 32 peserta didik mencapai KKM. Seluruh peserta didik atau $100 \%$ peserta didik sudah memahami materi pembelajaran. Pengalaman peserta didik dalam mengerjakan soal interaktif media quizizz dapat meningkatkan pemahaman peserta didik dalam memahami materi pembelajaran.

Rentang Nilai Peserta Didik Dua Siklus

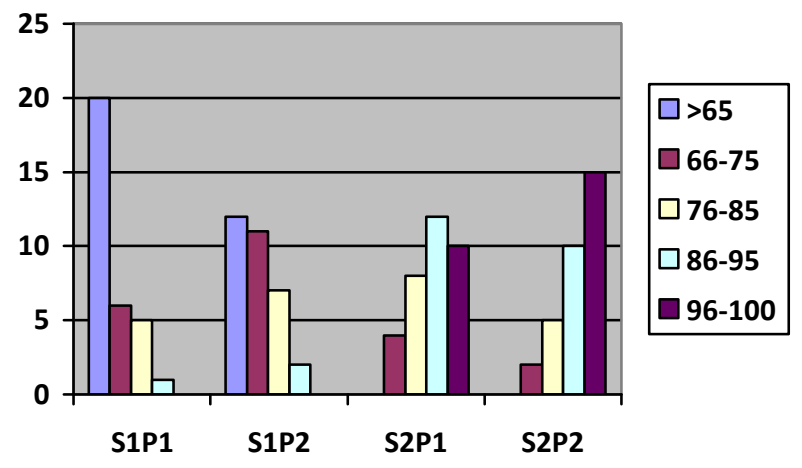

Diagram 1. Rentang Nilai Peserta Didik dalam Dua Siklus 


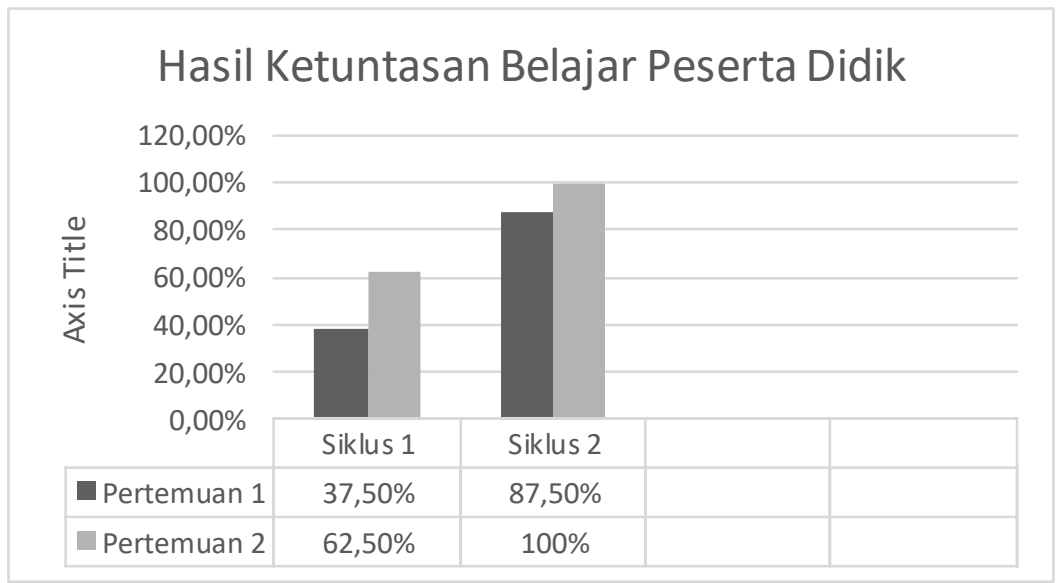

Diagram 2. Hasil Ketuntasan Belajar Peserta Didik dalam Dua Siklus

Hasil dari penelitian dua siklus dapat disimpulkan bahwa terjadi peningkatan hasil belajar peserta didik menggunakan media quizizz sebagai aplikasi kegiatan evaluasi pembelajaran. Peningkatan hasil belajar peserta didik menunjukkan bahwa pemahaman peserta didik terhadap materi pembelajaran meningkat. Hal tersebut menunjukkan bahwa penggunaan media quizizz sebagai aplikasi kegiatan evaluasi pembelajaran dinyatakan efektif dan efisien digunakan. Hal ini sejalan dengan penelitian dari Mulyati dan Evendi (2020:72) yang menyebutkan bahwa media quizizz layak digunakan sebagai aplikasi evaluasi pembelajaran karena dapat meningkatkan hasil belajar peserta didik. Selain mudah digunakan, quizizz dapat menyajikan hasil penilaian dengan cepat.

Fazriyah, Cartono, dan Awangga (2020:203) menyebutkan bahwa penerapan quizizz sebagai aplikasi mobile learning dapat meningkatkan keterampilan guru dalam mengajar. Kemudian, ketika aplikasi tersebut diterapkan pada kelas tinggi membuat peserta didik menjadi lebih semangat belajar serta memudahkan guru dalam mengevaluasi peserta didik.

Media quizizz sebagai aplikasi evaluasi pembelajaran dinyatakan efektif karena mampu meningkatkan hasil belajar dan pemahaman materi peserta didik. Media tersebut dinyatakan efisien karena menghemat penggunaan kertas, praktis digunakan oleh guru maupun peserta didik, dan hasilnya dapat dikirim langsung ke orang tua peserta didik sebagai laporan. 


\section{SIMPULAN}

Berdasarkan hasil penelitian mengenai peningkatan hasil belajar tema 3 melalui media quizizz sebagai aplikasi evaluasi pembelajaran di kelas VI A SDN Guntur Kota Cirebon, peneliti dapat menyimpulkan sebagai berikut. (1) Media quizizz sebagai aplikasi kegiatan evaluasi pembelajaran memiliki banyak fitur yang dapat dimanfaatkan guru untuk kegiatan evaluasi pembelajaran. Fitur yang dimiliki quizizz di antaranya adalah terdapat 5 jenis pertanyaan interaktif yaitu pilihan ganda, isian, uraian, polling, dan daftar ceklis. Quizizz dapat dimainkan secara individu maupun kelompok. Aplikasi ini juga dapat dimainkan secara langsung maupun dapat sebagai tugas/ pekerjaan rumah. Aplikasi quizizz memudahkan guru untuk melakukan anasilis soal dan jawaban peserta didik, serta dapat mengirimkan hasil quizizz kepada orang tua peserta didik melalui e-mail. (2) terjadi peningkatan hasil belajar peserta didik melalui media quizizz sebagai aplikasi kegiatan evaluasi pembelajaran dari $37,5 \%$ meningkat menjadi $62,5 \%$ pada siklus pertama. Kemudian, terjadi peningkatan pada siklus kedua sebesar $87,5 \%$ pada pertemuan pertama dan $100 \%$ pada pertemuan kedua. Hal tersebut menunjukkan bahwa penggunaan media quizizz sebagai aplikasi kegiatan evaluasi pembelajaran dinyatakan efektif karena mampu meningkatkan hasil belajar dan pemahaman materi peserta didik. Selain itu, media quizizz dinyatakan efisien bagi guru dan peserta didik karena mudah digunakan, lebih hemat dalam penggunaan kertas (paperless), dan dapat dikerjakan dimana pun dan kapan pun.

\section{DAFTAR PUSTAKA}

Abidin, Y. (2013). Pembelajaran Bahasa Berbasis Pendidikan Karakter. Bandung: PT Refika Aditama.

Citra, C.A. dan Rosy, B. 2020. Keefektifan Penggunaan Media Pembelajaran Berbasis Game Edukasi Quizizz Terhadap Hasil Belajar Teknologi Perkantoran Siswa Kelas X SMK Ketintang Surabaya. Jurnal Pendidikan Administrasi Perkantoran (JPAP). 8(2): 261-272.

Fazriyah, N., Cartono, dan Awangga, RM. 2020. Pelatihan Aplikasi Pembelajaran Quizizz Di Sekolah Dasar Kota Bandung. Jurnal Penelitian dan Pengabdian Masyarakat. 8(2): 199-204.

Mulyati, S. dan Efendi, H. 2020. Pembelajaran Matematika Melalui Media Game Quizizz Untuk Meningkatkan Hasil Belajar Matematika SMP 2 Bojonegara. 
GAUSS: Jurnal Pendidikan Matematika. 3(1): 64-73.

Noor, S. 2020. Penggunaan Quizizz Dalam Penilaian Pembelajaran Pada Materi Ruang Lingkup Biologi Untuk Meningkatkan Hasil Belajar Siswa Kelas X.6 SMA 7 Banjarmasin. Jurnal Pendidikan Hayati. 6(1): 1-7.

Shoimin, A. (2014). 68 Model Pembelajaran Inovatif dalam Kurikulum 2013. Yogyakarta: Ar Ruzz Media.

Suprijono, Agus. (2012). Cooperative Learning. Yogyakarta: Pustaka pelajar.

Suyanto dan Djihad, A. (2012). Bagaimana Menjadi Calon Guru dan Guru Profesional. Yogyakarta: Multipressindo.

Wibawa, R.P., Astuti, R.I., dan Pangestu, B.A. 2019. Smartphone-Based Application "quizizz" as a Learning Media. Jurnal Dinamika Pendidikan. 14(2): 244-253. 